\title{
THE NEW EQUITY RULES OF THE UNITED STATES COURTS
}

\author{
By Prof. John Wurts.
}

On account of the enormous volume of judicial business to be affected, no such important change in procedure has ever been made as that about to be produced by the new rules of practice for the United States Courts of Equity, which will go into effect February I, I9I3. These new rules not only tend to simplicity and to the elimination of the delays which cause the lay mincl to hark back to Jarndyce $\approx$. Jarndyce, but they actually relegate to the historical shelf of the solicitor's lumber room much of the technical learning which was his stock in trade.

Rule days are abolished, or rather all days except Sundays and holidays are made rule days; subpœnas are returnable when served; the defendant's appearance as a special proceeding is abolished and the defendant's answer is due twenty days after the service of the subpœna.

Contrast the way causes will be speeded hereafter with the way they have been delayed heretofore. Until now, if a bill were filed on the I2th day of January, it might happen that the defendant could not be held to enter an appearance until the first Monday in May, and then he could not be compelled to disclose the nature of even a dilatory defense until the first Monday in June, and to predict the time within which a complainant could dispose of exceptions and demurrer and plea, and force the defendant to an issue on the merits would be to risk one's reputation as a prophet.

Now, the defendant must file his answer twenty days after service of the subpœna, and, as replications are abolished, except in special cases, the cause is then at issue and ready for trial.

Pleas and demurrers are abolished and with them is removed half of the difficulties besetting the path of the equity practitioner. Gone is the learning respecting answers in support of pleas; gone are the certificates of counsel and the affidavits negativing delay; together with the plaintiff's summary action where they are omitted. So also there is no longer dismissal of the bill for plaintiff's failure to file the general replication or to "set down for hearing". 
$\lambda$ bill is no longer to be dismissed for want of equity, if it shows a legal cause of action, but is to be transferred to the law side of the court.

The frame of bills is simplified and all bills praying interloctrtory relief must be verified. Moreover, a vast saving to litigants, both in costs and in counsel fees, is effected by permitting the joinder of causes of action.

The defendant is unlimited in the number of his defenses, regardless of consistency. Matters heretofore of plea or demurrer may be set up in the answer, which may also be treated as a crossbill.

Exceptions for insufficiency of the answers are abolished and the common-law doctrine of constructive admission by pleading is introduced.

Not the least revolutionary of these rules are those providing that, in general, the testimony of witnesses shall be taken orally in open court and that appeals shall be heard upon a condensed record.

Altogether, these rules indicate a most determined effort on the part of the highest court of the land to bring about a reform which the public has long been demanding.

Nerv Haven, Conn.

John Wurts. 